\title{
Educating Foreign Language Primary School Teachers: A Review of Models of Teacher Education and New Proposal
}

\author{
Jesús Alirio Bastidas Arteaga \\ Universidad de Nariño, Pasto, Nariño, Colombia
}

\section{Introduction}

The 1980's and 1990's experienced important changes in the teaching of target languages in most of the countries of Europe and Latin America, that is, the implementation of another language in primary schools, either as a second (L2) or a foreign language (FL). In a large part, this innovation in the educational systems of each country is due to social, political, economic, cultural, and educational trends affecting the world at the end of the twentieth century (Doyé \& Hurrell 1997). Due to the importance of English as an "international language” (Brutt-Griffler 2002; Mackey 2002), this has become one of the most common foreign languages introduced in primary school.

Although the previous innovation was welcomed by political and Educational authorities in most of the countries, some academic and teaching staffs were skeptical about this decision, mainly and most importantly, because what we got was an international "cart before the horse" decision, that is, the decision was incorporated as a policy in the educational laws or reforms of most of the European and Latin American countries, but the bottom-line was, there were few or no teachers qualified to teach FL in primary schools (Bastidas 1992a). However, for the government and educational authorities it appears that the solution was quick and easy: FLs had to be taught by primary school teachers (the so called generalists), and all they needed were some short and intensive teacher-training courses both in FL improvement and FL teaching methodology. It is interesting to see that after more than twenty years of the implementation of foreign languages in primary schools, Eurydice (2008) reports: "In the majority of countries, they are taught at this level by general teachers qualified to 
teach all (or almost all) subjects in the curriculum. This applies whether the language concerned is a compulsory subject or a core curriculum option.” (p. 77).

Taking into account that the implementation of a FL in primary schools became a language policy that transcended the educational systems of many countries, the academic staff of higher education institutions (HEI) has had to introduce changes in the programs of language education, which had been preparing speciliazed teaching professionals to teach FLs in secondary schools up until the 1980's or 90's (Bastidas 1992b, 1993). Nevertheless, a question arose: What kind of teacher preparation should these programs include in order to qualify the teachers to fulfill the aims of the new policy? To answer this question, it is necessary to refer to some models of teacher education programs.

\section{Models of teacher education}

Various authors have referred to models for preparing professionals in general disciplines, specifically, the preparation of teachers. For example, Wallace (1991) refers to three models: the craft model, the applied science model, and the reflective model.

Craft models are based on the concept that knowledge and experience rest in the hands of the experts or professionals, and they are transmitted and demonstrated to learners, so that they observe, imitate, repeat and learn. Applied Science Models provide learners with theoretical knowledge based on the available scientific, theoretical and philosophic research results, so that they can apply this knowledge in practice in order to solve concrete problems. Reflective models are based on Schön's (1983) proposals concerning the way that professionals solve problems through reflection and improvisation through their actions in practice. Based on these notions, Wallace (1991) proposed a reflective model composed of two types of interrelated knowledge: received knowledge and experiential knowledge. In addition, practical knowledge is developed through continuous reflection - in and on action, which consists of thinking about, questioning, analyzing, and evaluating practical activities in order to improve, transform or change them. 
The introduction of a FL in primary schools motivated some authors to design and propose more specific teaching models or frameworks to prepare FL educators, which have been based on the general models presented above. As far back as 1991, Williams stated the need to design a specific model for teaching young children based on education and applied linguistics for the teaching of English. From education, Williams takes some aspects from primary school teaching, such as 'learn by doing' and the importance of both learning and contents. As a result of those premises, methods based on discovery, learning based on activity, and the project or theme based approach have been developed. From Applied Linguistics, Williams acknowledges the importance of knowledge about L2 acquisition, the communicative approach, and authentic language. Additionally, he emphasizes the importance of attitude and motivation, which serve to facilitate or to inhibit children's learning, favoring a methodology based on contents or activities and which served as a basis for a research project for primary education in Singapore.

Another author who refers to two teaching models is Felberbauer (1997). The first one was designed by a group of teachers and teacher trainers from nine European countries who met in Prague in 1992. This model includes four components related to Education: FL methodology, Linguistic and Cultural studies, and Psychology, all of which encompass specific knowledge bases to be developed in training programs such as:

Education: Primary education, language education, and intercultural education.

FL Methodology: Aims and objectives, methods and procedures, media, evaluation.

Linguistic and Cultural Studies: Theory of language (including Pragmatics), theory of culture (including Intercultural Relationship)

Second Language: grammar, lexicology, and phonology.

Psychology: Developmental Psychology, Psychology of Learning, Social Psychology, and Psycholinguistics.

The second model was the result of a workshop done in 1995. According to Felberbauer (1997), this reflective model states that the students' classroom practical work is based on theory. In addition, the theoretical knowledge is modified by the classroom experience, as is shown by the solid arrows in Figure 1. Furthermore, in the 
school teaching practicum, the students get stimuli for their theoretical work, which can affect their classroom performance, as the hyphened arrows indicate, also in Figure 1.

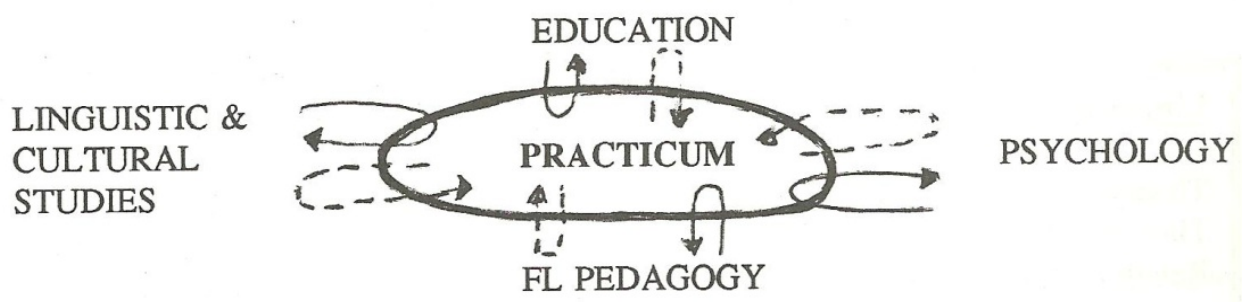

Figure 1. The in-service training model (Report on Workshop 8A, 87), (Felberbauer, 1997)

In this model, theory and practice play a similarly important role in successfully training teachers. As can be seen, the model keeps the same components of the previous model, that is: Education, Linguistic and Cultural Studies, FL Pedagogy and Psychology and incorporates the Practicum as the main activity of teachers' training.

Recently, Durán, Sánchez-Reyes, and Beltrán (2004) have adapted Stern’s language teaching model (1983) to serve as a framework to prepare FL primary school teachers. This model is composed of three levels: the first one represents theoretical knowledge coming from such disciplines as: Linguistics, Psycholinguistics, Sociolinguistics, History of Language Teaching, Sociology, Psychology, and Educational Theory. The second level includes theoretical and research information about learning, language, teaching, and context, and the third level represents practical knowledge, labeled as Educational Linguistics, which is composed of two areas: methodology and administrative organization.

Finally, according to a Eurydice report (2005), in most of the European countries, the initial FL teacher preparation is centered on FL methodology and practical formation, which are generally developed by means of four activities: 1) Learning of one or more FLs, 2) theoretical courses of FL methodology, 3) teaching practice in schools, and 4) short-term trips abroad. However, the last activity is not mandatory in most of the European countries, except Luxembourg and the United Kingdom (Scotland).

In summary, most of the models described above are based on the applied science conception, with the exception of the second model presented by Felberbauer 
(1997) which is described as a 'reflective model for initial teacher training'. Although, the models based on applied science conceptions have been used to support professional preparation in most of the disciplines, they have been questioned since the 1980's for many reasons (Schön 1983; Wallace 1991; Bastidas 2009). On the other hand, those models based on reflective conceptions seem to be more effective for preparing teachers with a variety of practical activities and for helping them develop an awareness of the close relationship between theory and practice. However, they still have a tendency to include a series of disciplines, which run the risk of presenting specialized knowledge in general (e.g., theories of linguistics for linguists, developmental psychology for psychologists, etc), and most seriously to offer the courses in isolation, that is divorced from pedagogy and the FL practice component.

\section{Towards an alternative approach to educate pre-service FL primary school teachers}

I will now refer to a model to prepare FL primary school educators based on contemporary curriculum conceptions. For the purpose of this article, it has been called 'a model based on curriculum to educate FL primary school teachers', which has been adapted from a general model previously proposed (Bastidas 2009). The name implies that one uses contemporary conceptions of curriculum to support its nature in order to design, implement and evaluate a program of study. My reasoning is that if the programs of study of any discipline are essentially composed of curricula, then they have to be based on curricular conceptions and designs, which at this time show advancement and improvement compared to curricula proposed in the first part of the twentieth century, such as the technical and practical approaches. The present model is based on the so-called transitional and critical curriculum approaches (Schwab 1974; Carr \& Kemis 1988; Stenhouse 1991, 1993; Goyes \& Uscátegui 2000). Also, a curricular approach allows me to support those proposals which consider that any preparation of FL teachers for primary school should take into account the nature, approaches, methods, and procedures of good primary school teaching (Brewster 1991; Williams 1991; Doyé \& Hurrell 1997). 
Additionally, I use the word educators, because what we need is qualified educators, not only teachers, instructors or trainees. This concept is influenced by Strevens, who, as long ago as 1978 observed:

It is possible to discern three different stages of language teaching activity [...] the first is that of the INSTRUCTOR, who is able to manipulate the techniques of language instruction who knows the course-books and materials in use for his particular pupils, and who presents the foreign language material with adequate competence to his or her students. The second is that of the TEACHER, who is a good instructor and more. The good teacher cherishes his pupils, knows them, understands their individuality as learners, recognizes their learning preferences and their difficulties, and sees their language learning progress on a time-scale greater than simply that of the class, the week, the semester or the year. The third is that of the EDUCATOR, who is a good teacher, but whose perspective is wider, who thinks of the students in relation to the whole of their needs for tuition and training, and who is aware of the interrelations between the techniques of language teaching, the contributory disciplines, and the needs of society.” (Cited in Bastidas 1991: 5)

Furthermore, nowadays the idea of training has been questioned because it implies a behaviorist approach to train teachers at the level of technique in a (mechanical) rote and imitative way, in favor of an idea of education. This means that the preparation of undergraduate students is based on humanistic and educational approaches, contemporary theoretical principles and appropriate methodologies, reflective practices, experiential knowledge, etc. Additionally, these students have to be prepared in the concept of teaching or professional development, which implies that future teachers have to be autonomous, collaborative, innovative, flexible, and open to changes and innovations in their general and specialized areas of expertise.

Below I present a diagram to represent the model for preparing primary school FL educators. 


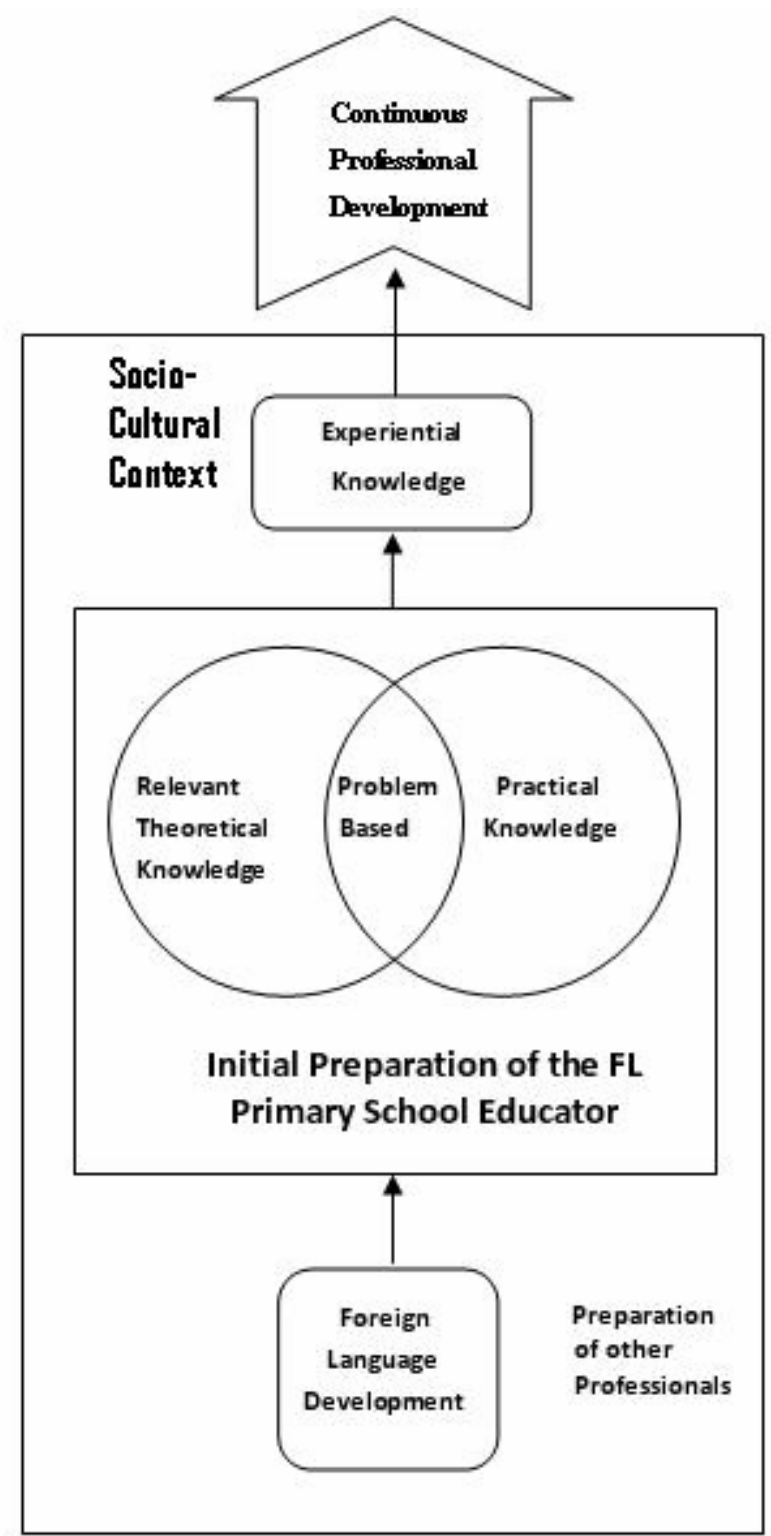

Figure 2. Model based on curriculum to educate FL primary school teachers

First, I refer to the knowledge base or contents of a program of education of FL teachers for primary school, and then to some of the learning and teaching activities, that is the process, that can be used to implement the program.

Knowledge Base of the Program: The model shows that the first component to be developed is the study of the FL, both as a skill in the first cycle, and as an object of understanding in the second cycle. This means that in the first stage of the program, which could be labeled a basic cycle, the under-graduate students commit to the study of the FL until they can reach at least a high-intermediate level, equivalent to the B2 
equivalent of the Common European Framework Reference for Languages. This means that at the end of the courses, the students will take a standardized international test in order to demonstrate their high intermediate level of language proficiency, according to the regulations of the Higher Education Institution (HEI). The duration of this cycle will depend on the prospective students' entrance level of FL language proficiency, the intensity of the daily and weekly schedule of FL classes, and the academic demands of the type of language development courses included in the program. It would probably last between one and three semesters.

Once the students have passed the previous basic cycle, they would have the chance to select a variety of professional studies related to languages. That is, the HEIs could have the opportunity to design and implement different programs, such as: FL education for primary school, FL education for secondary school, bilingual education, translation and interpretation, language and literature, philology, FL literature, tourism and languages, bilingual executive secretariat, etc. In some countries, these programs would be novel because, in the field of languages, some HEIs only offer programs of FL education; that is, the students who do not want to be teachers will have the opportunity to choose from a variety of under-graduate professional programs related to languages. Another advantage of ensuring a good command of the FL language at this stage is that the contents of the next cycle can be developed completely in the FL language, so that the students continue developing and improving their language proficiency and we can make sure that any lack of a sufficient proficiency level does not negatively affect their academic performance in the subjects taught through the FL, as might be happening in the programs nowadays.

The programs related to FL education will include a second cycle, which corresponds to the professionalization in education, in our case, in FL education for primary school. According to the model the initial preparation of the FL primary school educator will be composed of three types of knowledge: relevant knowledge base (Burns \& Richards 2009), practical knowledge and experiential knowledge. As shown in the diagram (figure 2, above), the first two types of knowledge are immersed into two concentric circles that overlap. This overlap indicates that the practical knowledge available to the students in the schools will be analyzed and interpreted through the lens of the knowledge base provided in the course of studies at the HEIs. In addition, this 
representation is meant to show the need to switch the traditional site of higher education from the HEI to the school site, that is, beginning with the first semester of professional studies, the students will be situated in schools for at least half of the timetable, in order to be aware of school life, not only in the classroom, but also in the context of the school and the community. This means that they will be there to study the setting, not to do teaching practicum. In addition, the responsibility of the preparation of the primary school educators will not only be in the hands of the university professors, but also in the primary school teachers'. To accomplish this ideal, there is a need to establish official academic agreements with the primary schools, so that they facilitate the students' presence and action, and they permit the teachers to play a new role: students' mentors, which will require the need to start a process of preparation and development on the part of the primary school teachers.

In order to analyze, evaluate and produce these types of knowledge, I propose a series of what I call nucleus based on problems, a pedagogical model derived from the so-called “enseñanza problémica”. In addition, student-teachers will also take further some relevant and essential disciplinary courses or seminars related to the study of the FL as an object of study (e.g., phonology, morphology, syntax, semantics and pragmatics), so that they get a solid understanding of how the FL is structured and is used in a socio-cultural context. These courses will also serve to help students develop their proficiency level in the FL.

As stated before, the curriculum approach that I am proposing is based on the “enseñanza problémica” pedagogical model. According to Danilov and Skatkin (1978), in this type of teaching the students look for the solution of novel problems guided first by the teachers, and then in groups or individually. In this way they learn to acquire knowledge in an independent way, to take into account their previous knowledge and to master a creative way of thinking. Based on this pedagogical model, the contents of the program can be organized into a nucleus, based on themes and problems, as is shown in the following table. 
Table 1. Thematic and problem based nucleus

\begin{tabular}{|c|c|}
\hline Thematic Nucleus & Nucleus based on Problems \\
\hline Language Learning & $\begin{array}{l}\text { Grand tour question: } \\
\text { How and why are both L1 and L2 learned? } \\
\text { Sub-question: } \\
\text { Why are target languages not learned in a foreign } \\
\text { context satisfactorily? }\end{array}$ \\
\hline Language Learning Context & $\begin{array}{l}\text { Grand tour question: } \\
\text { How and why does the context affect L1, L2 } \\
\text { learning? } \\
\text { Sub-question: } \\
\text { How and why does the context affect FL learning? }\end{array}$ \\
\hline Language Learning through teaching & $\begin{array}{l}\text { Grand tour question: } \\
\text { How can teachers teach so that students learn a L2 } \\
\text { and/or a FL satisfactorily? } \\
\text { Sub-questions: } \\
\text { Why do many students not learn a L2 or a FL } \\
\text { satisfactorily through teaching? } \\
\text { How can student-teachers be successful in } \\
\text { facilitating language learning in primary school } \\
\text { children? } \\
\text { How can media facilitate FL language learning in } \\
\text { primary school? }\end{array}$ \\
\hline Professional development & $\begin{array}{l}\text { Grand tour question: } \\
\text { After graduating from the university, how can } \\
\text { professional development be done? } \\
\text { Sub-question: } \\
\text { Why do people resist to change and innovation? }\end{array}$ \\
\hline
\end{tabular}

The previous themes and problems are meant to be examples of the key issues that form the core of the program of studies, so that the HEI can use them, add other questions, and sequence them according to the purposes and profiles of the undergraduate students. However, it is advisable that in the first semester of the professional cycle, some themes and problems related to the educational context, especially the primary school context, and to the process of initial research be studied. The purpose of such a study will be to make the students aware of the responsibilities implied in being a FL teacher in primary school and to develop the basic competences of research to be used in the following semesters. In addition, in the first year of the second cycle, selected courses or seminars related to the FL as an object of knowledge, communication, and recreation will be included. A representation of the themes and its possible sequence is presented below in a spiral, which indicates that the knowledge and 
experience attained in every semester or year will be recycled, so that the students' previous knowledge will always be taken into account, the knowledge gotten previously will be reviewed, and the new knowledge linked to this knowledge.

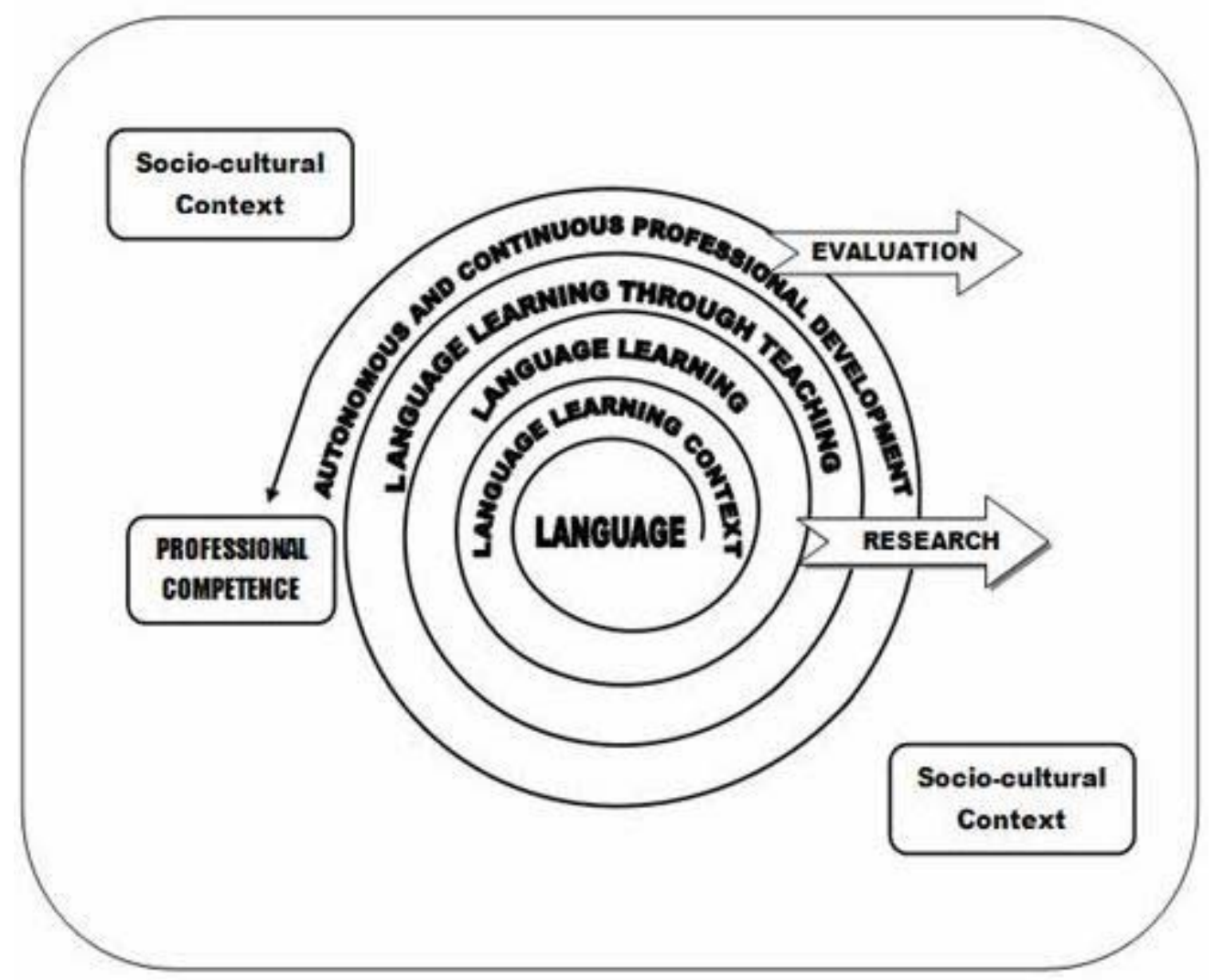

Figure 3. Organization of the nucleus based on problems in the course of study

The pedagogical model proposed for the program of study emphasizes an organization based on research questions, which require answers from an interdisciplinary and a trans-disciplinary perspective. This means that professors of the program, working in teams, have to be selective of the relevant knowledge base coming from all the disciplines related to primary education, language, language learning, language use, FL teaching, intercultural communication, technology of information and communication, and FL professional development that contributes to understanding and explaining the complexity of the process of language learning and teaching, either first, second or foreign. Furthermore, the so-called founding disciplines (Stern 1983) will not become the core courses to be studied theoretically and in isolation from the FL teaching component, as it usually happens in the language programs based on an applied science model (Freeman 1989). 
A program based on a curriculum approach and on a problem based model also has the advantage of requiring a planning, implementation, and evaluation process based on inquiry, reflection and research in order to look for answers to the questions proposed in each nucleus. In this way, the program would show that research permeates the whole curriculum. On the other hand, a program based on a curricular approach requires that evaluation becomes a continuous, permanent and flexible mechanism in order to assess students' learning and give feedback to all the curricular components in order to improve the program of studies.

At the very top of figure 2 (above) the model shows the final component of the program: experiential knowledge, a term borrowed from Wallace (1991), which represents the knowledge and skills that pre-service educators will get from various forms of practical activities, such as: peer teaching, reflective classroom observation, internships, teaching practice (Richards 1998), and reflective teaching seminars.

The model is enclosed within a frame which represents the socio-cultural context that surrounds the whole process of learning a FL and getting professional educational knowledge. Although this aspect can be analyzed in the nucleus of Language Learning Context, the program should take into account the role of the sociocultural context of the entire curriculum (Hawkins 2004; Tedick 2005). I certainly believe that it is a must of any language program offered in a FL language context to make students aware of and to introduce them to conduct research studies in order to describe, understand, explain, and evaluate the process of language learning in a foreign context. I do not deny the fact that the knowledge produced in the field of second language learning and teaching is important, but we have to continue studying our Foreign Language situation in order to produce knowledge, and not to just continue being consumers of knowledge coming from other disciplines and from other contexts. An example of a research agenda in learning and teaching languages in a foreign context has been proposed in Bastidas (2008).

In relation to the duration of the second cycle, I would propose spending between three and a half and four years, depending on the duration of the first cycle, so that the whole program can be developed in a maximum of five years.

Learning and teaching activities of the program: Each of the cycles can use the appropriate learning and teaching modes according to the nature of the academic units 
they comprise. For example, the FL development component will include the learning and teaching strategies according to the approach selected or designed by the teaching team in charge of designing the course of studies. That is, if the selected approach is Communicative Language Teaching, the modes will be chosen, adapted or designed according to this approach. However, in a FL context, it is also advisable to take into account the assumptions of the post-method condition in order to design the learning and teaching strategies of the program. These strategies will be based on the parameters of the post-method pedagogy proposed by Kumaravadivelu (2006), that is particularity, practicality and possibility. In addition, it is my strong belief that the FL methodology used in the undergraduate program should be the means, not only to develop the students' proficiency level, but also to get their initial preparation in FL Didactics in an inductive way.

In the second cycle, when the initial preparation of the FL primary school educators starts, the methodology process should be in accordance with the pedagogical model of the program. Good examples of teaching approaches for this type of model are project work, inquiry-based, research based, reflective teaching, and critical pedagogy. Additionally, they can use a series of teaching strategies, such as: brainstorming, discussions, debates, roundtables, panels, lectures, seminars and workshops. Wallace (1991) also suggests the use of jigsaw learning, Socratic techniques, task-based learning and tutorials, as examples of common modes of teaching and learning used in higher education. The previous activities can be structured and developed in large groups, small groups, pair work and individual work. Wallace also refers to some special kind of groupings, such as: buzz groups, cross-over groups, pyramid or snowball groups, and self-help groups (1991: 44-47). Taking into account that this proposal emphasizes the use of a research-based methodology to develop the FL education professional component, the following research procedures and techniques can be used in the program: classroom observation, primary school teachers' and children's interviews, document analysis, journals, field work notes, small-scale projects, case-studies, and action research.

To get experiential knowledge the students can do practical activities such as peer teaching, school tutorials, classroom observation, internships, and reflective 
teaching practice. Reflective teaching practices can include: teaching practice, journals, audio- and video recordings, etc. (Richards \& Lockhart 1994; Richards 1998).

\section{Conclusions}

Starting from the need generated by the requirement of introducing the teaching of FL in primary school since the 1980's in Europe and the 1990's in Latin America, some models to prepare professionals in Education and in FL teaching have been briefly analyzed. I have presented a model to educate FL teachers for primary schools based on curricular concepts. This model is open, flexible and subject to permanent revision. For example, at this moment the model can be based on problems, projects, or thematic nucleus, which can be developed by means of analysis, reflection, critical thinking and research, but further on, other types of pedagogical models can be used.

The core problem of the model to be studied along the development of the program is learning languages by means of teaching, from which a series of (grand) research questions are derived and can be studied starting from the educational reality or practice and theorizing them based on the available knowledge, related research findings and university professors' and school teachers' pedagogical experience. This means that the disciplines related to learning and teaching languages will not be studied in isolation from the pedagogical component, but they will be the means to provide appropriate and relevant knowledge to understand, interpret and explain the process of learning languages (L1, L2, FL) in a natural context and through teaching from an interdisciplinary and a trans-disciplinary perspective. Finally, this model promotes the interaction between the HEI and the primary school settings from the first year of studies, due to the fact that the object and participants of research are localized in schools. This way, theoreticians, experts, pre-service teachers and primary school teachers will share knowledge and experience in order to form communities of practice and research, which will become the source of learning for the participants.

The model proposed in this article is under construction and development; that is, it is open to question and betterment. Once the model is designed according to curricular guidelines, it can be put into practice to be validated through experimentation and evaluation. 


\section{References}

Bastidas, J. A. (1991). 'EFL'in the Colombian high schools: From ivory tower to the poorest high school. Lecture presented in the $26^{\text {th }}$ Annual National ASOCOPI Convention. Santafé de Bogotá, D. C. October 11-14.

Bastidas, J. A. (1992a) English in primary school: Pros and cons of the new Colombian law. Lecture presented at the 27th ASOCOPI Convention. Universidad del Valle, Cali, Colombia.

Bastidas, J. A. (1992b) Propuesta de licenciatura en Educación Básica: Area Inglés. Pasto: Universidad de Nariño.

Bastidas, J. A. (1993) Licenciatura en Educación Básica: Area Inglés. Propuesta aprobada por los Consejos Académico y Superior mediante acuerdo No. 158 de noviembre 25 de 1993. Pasto: Universidad de Nariño.

Bastidas, J. A. (2008) La investigación en el aprendizaje y la enseñanza del inglés como lengua extranjera. Hechos y Proyecciones del Lenguaje, 16-17. 54-82.

Bastidas, J. A. (2009) Fundamentación teórico-Práctica de los Programas de educación en idiomas extranjeros. Revista Historia de Educación Colombiana, 12. 273-299.

Brewster, J. (1991) What is good primary practice? In C. Brumfit, J. Moon, \& R. Tongue. (Eds.). Teaching English to children: From practice to principle. (pp. 117). London: CollinsELT.

Brutt-Griffler, J. (2002). World Englishes: A study of its development. Clevedon, England: Multilingual Matters.

Burns, A., \& Richards, J. (2009) The Cambridge guide to second language teacher education. Cambridge: Cambridge University Press.

Carr, W., y Kemis, S. (1988) Teoría crítica de la enseñanza. Barcelona: Martínez Roca.

Danilov, I. M.A., and Skatkin, M. N. (1978) Didáctica de la escuela media. La Habana: Editorial Libros para la Educación.

Doyé, P., \& Hurrell, A. (1997) Foreign language learning in schools. Germany: Council of Europe Publishing.

Durán, Sánchez-Reyes, and Beltrán. (2004) La formación del profesorado de lengua inglesa en un contexto europeo. Salamanca, España: Editorial Ambos Mundos.

Eurydice. (2005) Cifras clave de la enseñanza de lenguas en los centros escolares de Europa. Madrid: Eurydice Unidad Española.

Eurydice. (2008) Key data on teaching languages at school in Europe. Brussels: Education, Audiovisual and Culture Executive Agency.

Freeman, D. (1989) Teacher training, development, and decision making: A model of teaching and related strategies for teacher education. TESOL Quarterly, 23(1). 2746.

Felberbauer, M. (1997) Teacher Education. In P. Doyé, \& A. Hurrell. (Eds.). Foreign language learning in schools. (pp. 77-85). Germany: Council of Europe Publishing.

Goyez, I. \& Uscátegui, M. (2000) Teoría curricular y Universidad. Pasto: Ediciones UNARIÑO.

Hawkins, M., R. (Ed.). (2004) Language learning and teacher education: A sociocultural approach. Clevedon, England: Multilingual Matters Ltd.

Kumaravadivelu, B. (2006) Understanding language teaching skills: From method to postmethod. Mahwah, N. J.: Lawrence Erlbaum Associates, Publishers.

McKay, S. L. (2002). Teaching English as an international language: Rethinking goals and approaches. Oxford: Oxford University Press. 
Richards, J. (1998) Beyond training. Cambridge: Cambridge University Press.

Richards, J., \& Lockhart, C. (1994) Reflective teaching in second language classrooms. New York: Cambridge University Press.

Schön, D.A. (1983). The reflective practitioner: How professionals think in action. London: Temple Smith.

Schwab, J. (1974) Un enfoque práctico para la planificación del currículo. Buenos Aires. El Ateneo.

Stenhouse, L. (1991) Investigación y desarrollo del currículo. Madrid: Morata.

Stenhouse, L. (1993) La investigación como base para la enseñanza. Madrid: Morata.

Stern, H.H. (1983) Fundamental concepts of language teaching. Oxford: Oxford University Press.

Tedick, D. J. (Ed.). (2005) Second language teacher education: International perspectives. Mahmah, NJ: Lawrence Erlbaum Associates.

Williams, M. (1991) A framework for teaching English to young learners. In C. Brumfit, J. Moon, \& R. Tongue. (Eds.), Teaching English to children: From practice to principle (pp. 203-212). London: CollinsELT.

Wallace, M. J. (1991) Training foreign language teachers: A reflective approach. Cambridge: Cambridge University Press.

\footnotetext{
Author references:

Jesús Alirio Bastidas Arteaga is Professor at the Universidad de Nariño, Pasto, Nariño, Colombia. He holds a Ph.D in Language, Literacy \& Learning (1999) and a M.S in Reading \& Writing (1996) from the University of Southern California, Los Angeles, CA, USA (LASPAUFulbright Scholar); M.A in Linguistics: TEFL (1983) from Ohio University, Athens, OH, USA (Fulbright Scholar). He also completed a Postgraduate Course in ELT (1992) at Thames Valley University, London, England (British Council Scholar). At present, he is pursuing Post-doctoral Studies in 'Didáctica de la Lengua y la Literatura' at Universidad Autónoma de Barcelona (Erasmus-Mundus Scholar). Recently, he was Visiting Professor at Central Washington University, Ellensburg, WA, USA (2008).
}

Email: jabas3@yahoo.es 